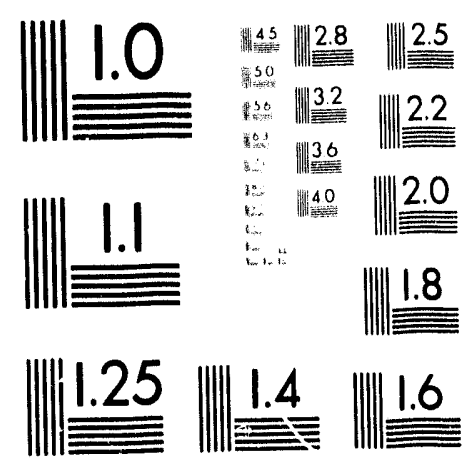



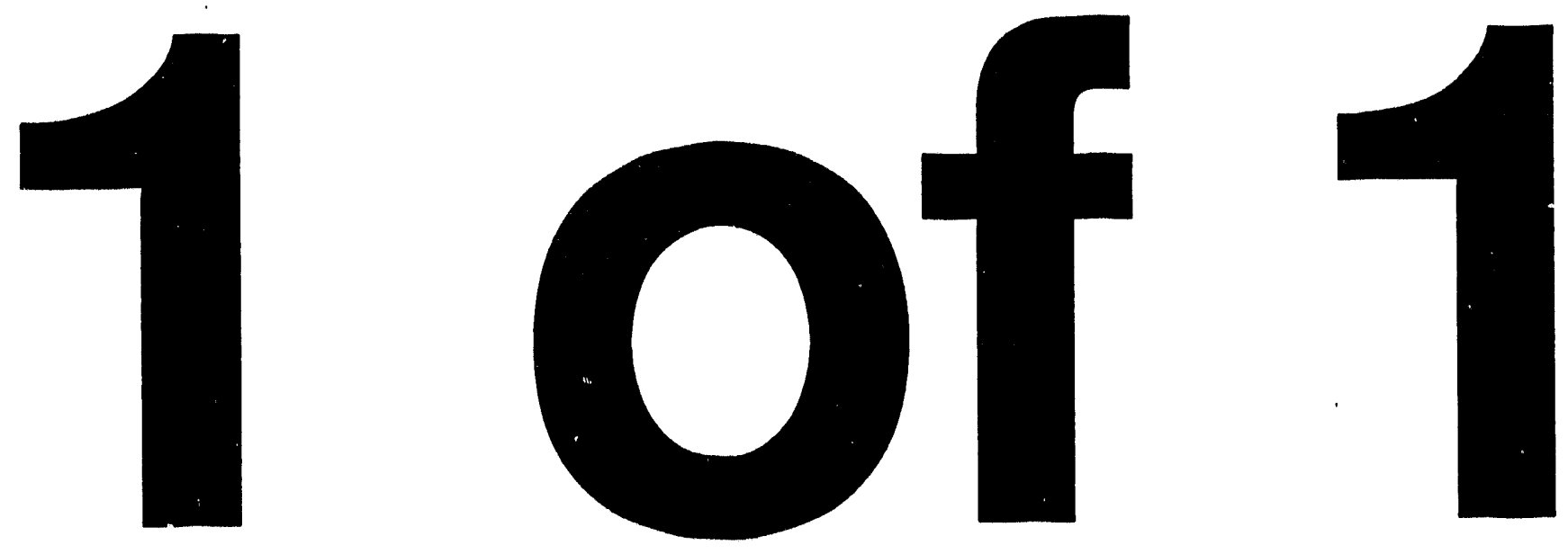

-

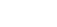




\title{
DOMESTIC REFRIGERATION APPLIANCES IN POLAND: POTENTIAL FOR IMPROVING ENERGY EFFICIENCY
}

\author{
Stephen Meyers and Lee Schipper \\ Energy Analysis Program \\ Energy and Environment Division \\ Lawrence Berkeley Laboratory \\ University of California \\ Berkeley, CA 94720 \\ Benoit L.ebot \\ Agence de l'Environnement \& de la Maitrise de l'Energie \\ Sophia Antipolis, France
}

August 1993

This work was supported by the Office of Environmental Analysis, Office of Policy, Planning, and Program Evalualtion, of the U.S. Department of Energy through the U.S. Department of Energy Contrict No. DE-ACO)3-76.SF()()(0)8. 


\begin{abstract}
This report is based on information collected from the main Polish manufacturer of refrigeration appliances. We describe their production facilities, and show that the energy consumption of their models for domestic sale is substantially higher than the average for similar models made in $\mathrm{W}$. Europe. Lack of data and uncertainty about future production costs in Poland limits our evaluation of the costeffective potential to increase energy efficiency, but it appears likely that considerable improvement would be economic from a societal perspective. Many design options are likely to have a simple payback of less than five years. We found that the production facilitics are in need of substantial modernization in order to produce higher quality and more efficient appliances. We discuss policy options that could help to build a market for more efficient appliances in Poland and thereby encourage investment 10 produce such equipment.
\end{abstract}




\section{INTRODUCTION}

The energy efficiency of energy-using equipment was historically not a high priorily in Poland or other centrally-planned economies, in part because energy prices were very low. As a result, the efficiency of the equipment in most areas is well below the levels typical in Westem Europe or the U.S. As Poland and the other former centrally-planned economies address the challenge of transtorming their economies and improving environmental conditions, improvement of energy efficiency has become an important policy goal.

In association with a larger study of energy use and energy efficiency in Poland, ${ }^{1}$ we undertook a more detailed analysis of the potential to improve energy efficiency in a single end usc, domestic refrigeration appliances. Much of the information presented in this report is based on discussions with the largest Polish manufacturer of domestic refrigeration appliances, a tour of their factory, and technical information provided by the company. As we were not able 10 conduct independent testing of Polish refrigeration appliances within the scope of this project, the findings on energy efficiency are not definitive, but they are probably reasonably accurate. A number of questions remam unanswered, calling for further research.

As shown in Figure 1, ownership of refrigerators rose rapidly in the 1970), and became nearly universal by $1989 .^{2}$ In the 1970 s very small (130) liter) refrigerators of Polish and Sovien mantufacture were most popular. A two-door Polish relrigerator-fiecer (220-240) liters) came on the market in the late 1970s, followed in the mid-1980s by a similar Soviel model. Based on interviews with Polish manufacturers, the Polish Foundation for Energy Elficiency (FEWE) estimates that 70\% of the total refrigerator stock of around 12 million units consists of models in the langer size range. ${ }^{3}$ The alverage retail price in early 1993 was $\$ 265$ for small units (130-170) liter) and $\$ 375$ for latrger models. ${ }^{2}$ Imported medels from Western Europe are considerably more expensive.

Ownership of freezers rose during the $1980 \mathrm{~s}$, and climbed further to ncarly $30 \%$ of homes in 1991 . An estimated two-thirds of frecers in use are quite small (50-60) liters), as many houscholds bought these small freezers to supplement the refrigerator they already owned. The remainder of the freeser stock is of 120-140 liter size. (In addition, there are an estimated 0.3-(1.4 million freezers with over 150 liters volume used by commercial enterprises.) Upright (front-open) freezers are more commen in cities, while larger chest freczers are more popular in rural areas, where llhey are used for storing meall. 'The alverage price in early 1993 was $\$ 280$ for small models and $\$ 375$ for the latger domestic model

The average energy consumption in use of Polish appliances is nol known will precision. Table 1 shows estimates made by FEWE based on spot metering of a small sample of devices. Multipying hese' values by the estimated number of units in use approximates total electricity consumption by einch lype of appliance. Refrigerators and freezers atecount lor an estimaled $20 \%$ and $5 \%$ respectively of hotal houschold electricity use. ${ }^{5}$

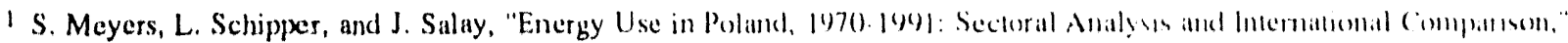
LBL-33994, Lawrence Berkeley Laboratory, Berkeley, CA, July 1993.

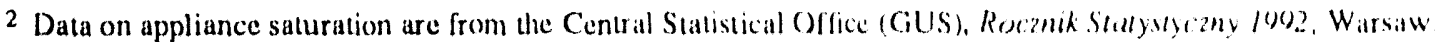

3 Estimates of the market shares of different appliance types and data on priees were provided by the Polsh Foumdiatum for Energy Efficiency (FEWE).

4 The larger models include both two-deor refrigerator-frecers and refrigerators with a froten food compartment.

5 Electricity use by Poland's 11 million households accounted for nearly $30 \%$ of total electrenty sales in 1901 . Electricily une

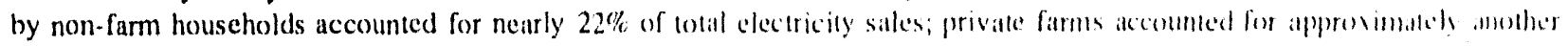
$7 \%$, and the majority of their electricity use is for houschold purjosess rather than farm machentery
} 


\section{Poland: Refrigerators and Freezers \\ 1975-1991}

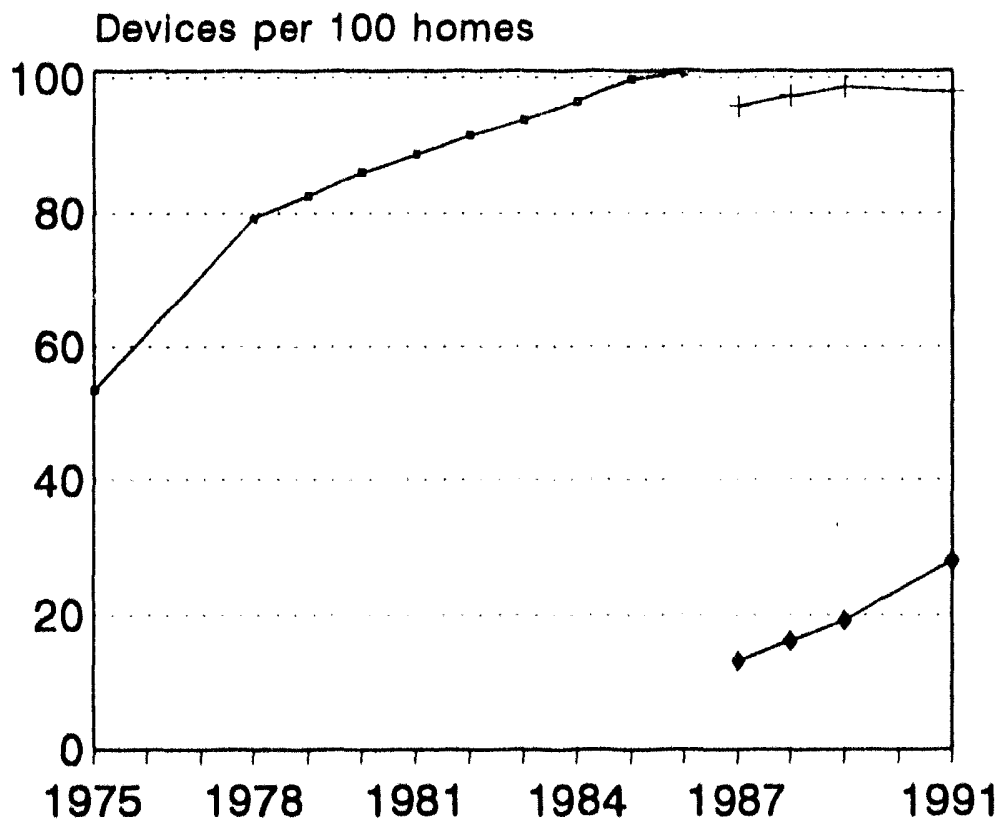

-Refrigs \& Freezers

+ Refrigerators

$\rightarrow$ Freezers

Source: Polish Central Statistical Office (GUS)

Fig. 1 


\begin{tabular}{lccc}
\hline \multicolumn{3}{l}{ Table 1. Estimated annual electricity consumption of appliances in Polish homes } \\
\hline Device & $\begin{array}{c}\text { Avg kWh } \\
\text { per device }\end{array}$ & $\begin{array}{c}\text { Number } \\
\text { (millions) }\end{array}$ & $\begin{array}{c}\text { Total use } \\
\text { (TWh) }\end{array}$ \\
\hline Refrigerators &.- & 11.91 & 5.41 \\
$135-1701$. & 410 & 3.57 & 1.47 \\
$220-2401$. & 475 & 8.34 & 3.94 \\
Freezers &.- & 2.27 & 1.34 \\
$50-601$. & 560 & 1.50 & 0.84 \\
$120-1401$. & 650 & 0.77 & 0.50 \\
TV sets &.- & 4.80 & 1.5 .28 \\
Storage water heaters &.- & 2.00 & 1.16 \\
All end uses & -- &.- & $-26.5 *$ \\
\hline
\end{tabular}

Source: Polish Foundation for Energy Efficiency, unpublished malerial Average consumption is based on spot metering of a small sample.

* Refers to the sum of residential sales and the estimitted household part of agricultural sales.

As shown in Table 2, Polish production of refrigerators and freecers has been fairly steady since 1985 at 500-600 thousand per year despite the severe economic recession of 199()-91. Imports, which were mainly from the Comecon countries and were equal to domestic production in 198.5, fell greally after the collapse of the Comecon trading structure. The domestic demand for refrigerators and freerers declined considerably in 1991 as the economic situation forced consumers to cut batek on expenditures.

\begin{tabular}{lcccc}
\hline \multicolumn{4}{c}{$\begin{array}{c}\text { Table 2. Polish production and trade of } \\
\text { refrigeration appliances (thousand units) }\end{array}$} \\
\hline & 1985 & 1989 & 1990 & 1901 \\
\hline & 578 & 516 & 606 & 56.3 \\
Production & 145 & 184 & 218 & 180 \\
Expont & $60(9)$ & 448 & 378 & 151 \\
Impont & 103.3 & 780 & 760 & 5.34 \\
Domestic supply
\end{tabular}

Source: Central Statisticial Oflice

Based on interviews with Polish manufacturers, FEWE estimates that atround two-thirds of the refrigerators sold in 1991 were of the larger size (220)-240 liters). For freecers, an estimaled $38 \%$ of 1991 sales were small (50-60 liters) units, 27\% were medium-size (100)-2(0) liters) units, and $36 \%$ were large commercial units. 


\section{PRODUCTION OF REFRIGERATION APPLIANCES IN POLAND}

This section provides information about Polar Industry, a state-owned company that accounts for around two-thirds of total production of refrigeration appliances in Poland. It is based on discussion with W. Babiarz, manager of the design department and deputy (hief designer of Polar, and on a visil lo the Polar factory in Wroclaw in July 1992.

Polar started the production of domestic refrigerators and freezers in 1950. In 1970), the factory wils enlarged to manufacture domestic clothes-washers. Annual production in recent years has been around 250 thousand refrigerators and 100-120 thousand freecers. Some 15-20\% of their refrigerators atre smallcapacity units of the absorption type. Around $40 \%$ of their refrigerators and freezers are exported under the "Sidex" trademark, mostly to Western Europe. Their refrigerators range in size from 130) 10 2.24) liters. The 240-liter model has a separate freezer compartment with alutomaltic delrost.

The appliances produced by Polar are well behind the state-of-the-ant in Western Europe and have not seen significant technological improvements in 15 years. The first refrigerators were produced with a license from Gorenje (in former Yugoslavia). Litlle hy litlle, Polar developed its own experlise and made various modifications to the initial design. Currently, Polar has its own industrial designs and pradices. but the last new product designed entirely at Polar was in 1975.

Although Polar has been using polyurethane foam for insulation since lle 197()s, manly of the components used in their products are outmoded. Hermetic compressors mainly come trom a company in the former East Germany and are rather inelicient. Polatr also purchases beller compressors from foreign companies such as Unidade Hermetica (Spain) and Danfoss (Denmatrk), but these are only used in relitgerators and frecers intended for export. They make their own door seals

The visit to Polar's factory made clear the very poor overall guality of the industrial instillation. The tooling plant has not changed since its foundation. Working ronditions seem unpleissunt: old machine tools, very noisy surroundings, and dirty buildings. The phising of redrigerator production is rather old-fashioned. The cabinet is built in one part of the building. The refrigeration unit, which consists of a compressor, an evaporator and the condenser, is assembled in another. It is lested for s) minutes, and then mounted on the cabinet. This implies that there is a thap on the backside of the cabine' to introduce the evaporator. Even if the trap is covered by an insulation shed, it allows lhermal losses. The scaling around the doors is also not optimized lo limil heal gains inside the cabinel.

The laboratory for research and development aclivilies wiss built all the sime lime as the latelory, but it is now being redesigned. Measurement tools, lest chambers and ofher monitoring apparatlus alle yuite old. There is not a single computer in the R\&D building. This is very surprising in a rescarch liblutallor! and is an illustration of the low investment capabilities of the company.

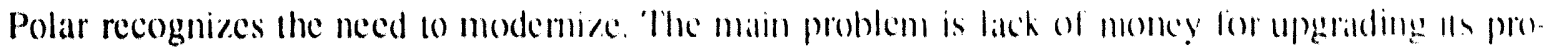

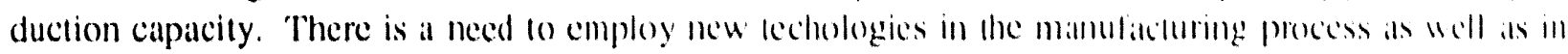
the products themselves.

Polar is adjusting to the new business environment in Polind. From 7060) workers in 1989), (1he company decreased to 5000 workers in 1992, but there is still over-employment. Politr is still stille owned, but it now has to make new kinds of stralegie decisions (matkeding, product development. new suppliers, etc.) that it never faced under the central planning regime. There wits no marketing under the old regime, only production largets. Product quality and energy elficiency were unimportant. Liverylhing

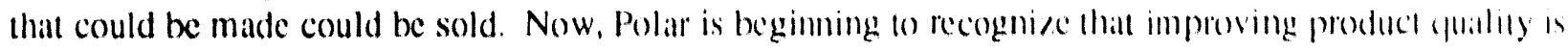
necessary, and they are looking more carelully all llo leatures of Weslem imports. 
Polar faces competition from producers to the East: Sniga (Lithuanian), Donbass (Russian) and Minsk (Belarus) all produce cheap refrigerators that are subject to low import duties. At the higher end of the market, they could face competition from Western products. In addition. their exports will soon meet lougher energy requirements in Western Europe. Meeting the CFC-reduction targets of the Montical Pro. tocol will also require investment.

Because the export market is important to Polar, its staff is very interested in the future of EC regu lation regarding domestic appliances, particularly concerning energy labelling and minimum efficiency standards. Many questions were asked on the technical approach and on the analysis of energy eflictency standards for domestic refrigeration appliances being carricd out for the Commission of the Europein Communities (discussed below). Questions were also asked on the introduction, organisaltion, control. and certification of energy labelling and efficiency standards.

\subsection{Energy Efficiency of Polar's Refrigeration Appliances}

The test chambers of Polar perform the same lest procedure that is used lluroughoul the EC (lle EN 153 norm, which follows the recommendations of the ISO). Thus, it is possible 10 malke a reasontably accurate comparison of the energy efliciency of Polish refrigetators and freceres wilh llose made in Westem Europe. Polar's electricity use measurement is matde with electromechanical coumlers and in men as accurate as the one used in Westem Europeall chambers, but the margin of error is relallively sllall

We analyzed the technical information collected from Polar using the sime methodelogy ats in a recent study of European refrigeralors and lieesers performed for the Commission of the European (ommunities." The methodology used is in many aspects similar to the U.S. DOS approitch an latr an alppliance category definition and use of the addusted volume insteid of the total volume

Under test conditions, the energy consumption of refrigeration appliances depends on the appliance volume and on the temperature difference between the surroundings and the inside of the appliance for devices with more than one compartment, the energy consumption depends on the relative side of the refrigerator and frozen food compartments. Therefore, it is preferable to use the adjusted volume rather than the net volume of the appliance. To calculate the adjusted volume, at correction is made for the relat tive contribution of compartments wilh different temperatures to the totill energy consumptiont. The adjusted volume is the sum of the volumes of the compartments, with calch weighted by the difference in lemperature between the interior of the compartment and the ambiemt lemperallure In the lest procedure EN153, the ambient temperature is set ill $25^{\circ} \mathrm{C}$.

In the United States, the minimum efficiency standiard uses the same lype of cialculation for adiusted volume, but the values for the weighting coeflicients are different becaluse both the ambient temperillure

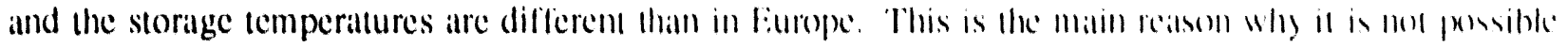
to compare the energy efficiency of Europeinn and $1 / S$. relrigeration anpliantes

We assume that the energy consumption of domestic refrigerattion appliances call be expresised as at linear function of the adjusted volume. The use of linear equations for energy consumplion in relation a) volume holds only when applied to well-delined product callegories A typical callegory of refrigeration appliances groups deviees that offer a common service rendered to the user. For example, He service rendered of a frozen food compartment depends on the teriperillure at which frozen hood is kept. The l:N15.3

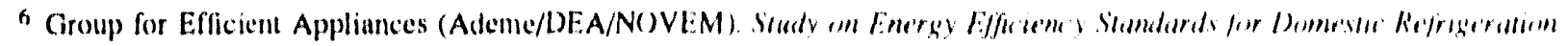

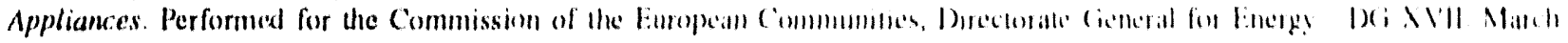
1993. 
test procedure identifies refrigeration appliance categories based on the temperature of the frozen food compartment (FFC), and proposes a star rating system to define appliance categories (sec below). The star rating of the frozen food or freezer comparment refers to its ability to maintain a specified lempera. ture and, in the case of a four-star frecer, 10 freeze a certain amount of product within a 24 -hour period. ${ }^{7}$

Refrigerators (with or without frozen food compartment) and combined refrigerator-frecers are primarily devoted to storing fresh fonds at at temperillure above $0^{\circ} \mathrm{C}$. According to the EN 15.3 test procedure, the storage temperature normally is $5^{\circ} \mathrm{C}$. Freecers (caltegories $\mathrm{F} 1$ and $\mathrm{F2}$ ) are used 10 freese foods and store frozen foods at a temperature of $18^{\circ} \mathrm{C}$.

It should be noted that in Europe the very large majority of the refrigeration appliances use miturall convection. Forced convection appliances offering the possibiliy of frost-frec operation just entered the morket 5 to 10 years ago, and their market share is still very low. Frost-free appliances are not pul in a scparate category but their energy efficiency is trealted with an adjustment factor applied to their chergy censumption in order to take into account the extra consumption due to the frost-free system.

The information on energy consumption and volume used in this antlysis comes from commercial brochures. Best would have been to get the daltil trom inn indepe sent laboralory, since commercial brochures are known to present data in a more optimistic way. The brochures mainly present the gross volumes of the compartments rather than the utilizable volumes that interest us. 'Thus, we estimilted the utilizable volume of the compartments.

Table 3 gives various statistics on the refrigeraltion appliances made by Polar. Including the energy. use reported in product brochures. From these ditlit we plolled the annual energy use vs. adjusted volumic for units in each applicable category (sec liggures 2 lhrough 6). (The cillegory R2 refers fo relrigerallors with a 2 -star FFC; R4 refers to refrigerator-freecers. To provide an additional poim of reference, He Figures also include appliances manufactured by calex, the main producer in the former cochosloviakia The figures depict how the energy consumption of the Bastem European models compares will hill ol similar models produced in the EC. The line with an index value of 1.0() is obtalined by a linear regres. sion on a scatterplot of all models produced in the EC in each callegory. (The data are from the sludy for

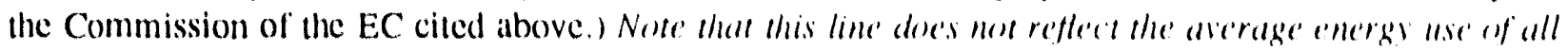
appliancess actually sold in the market. but rather the average of all comparable models an the market The other lines in the Figures refer to consumpliom levels that are at given percentalge above or betow the reference line.

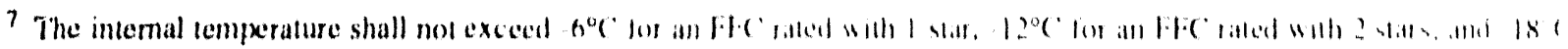
for an FFC rated with 3 or 4 stars
} 


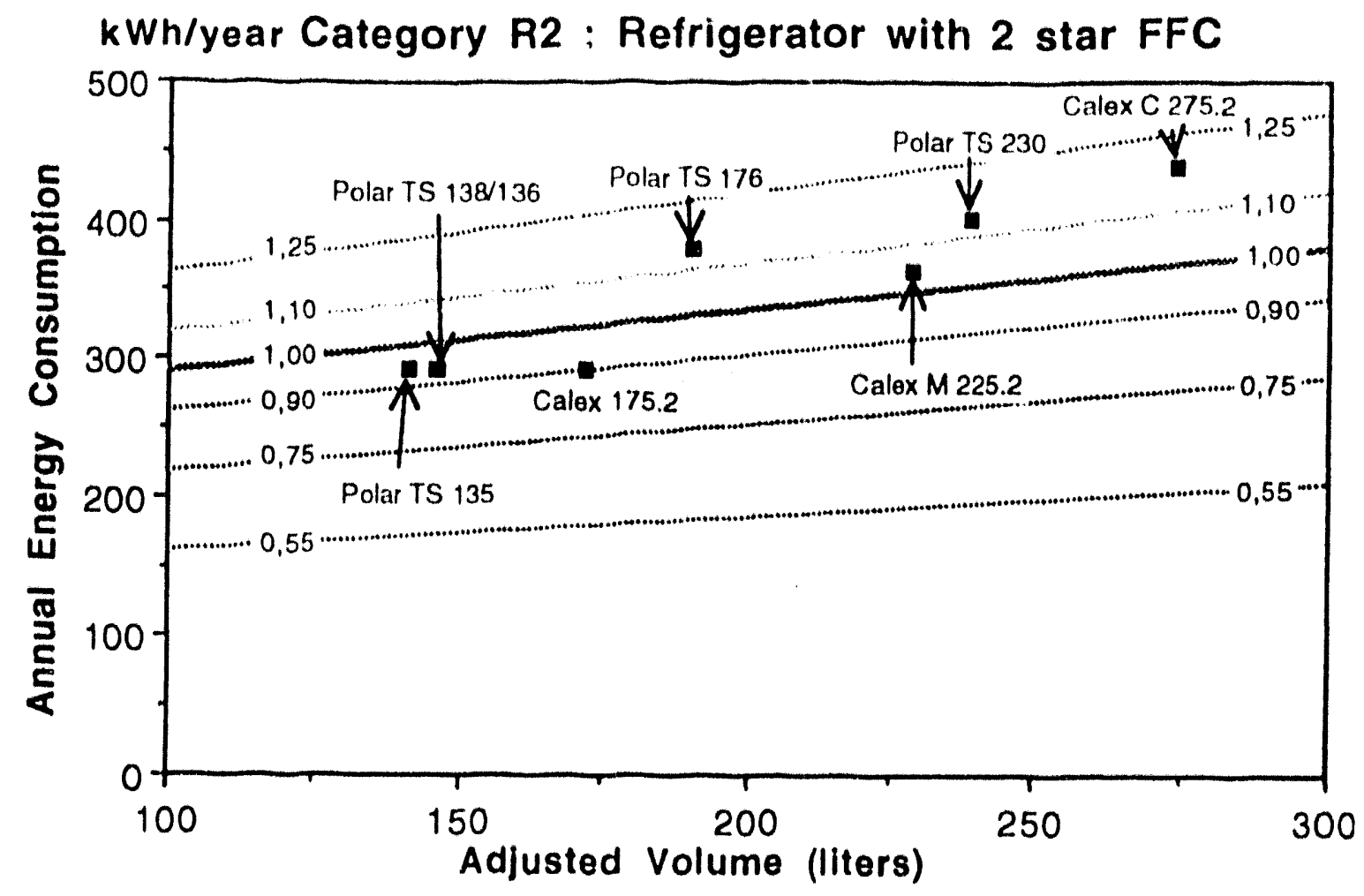

Figure 2

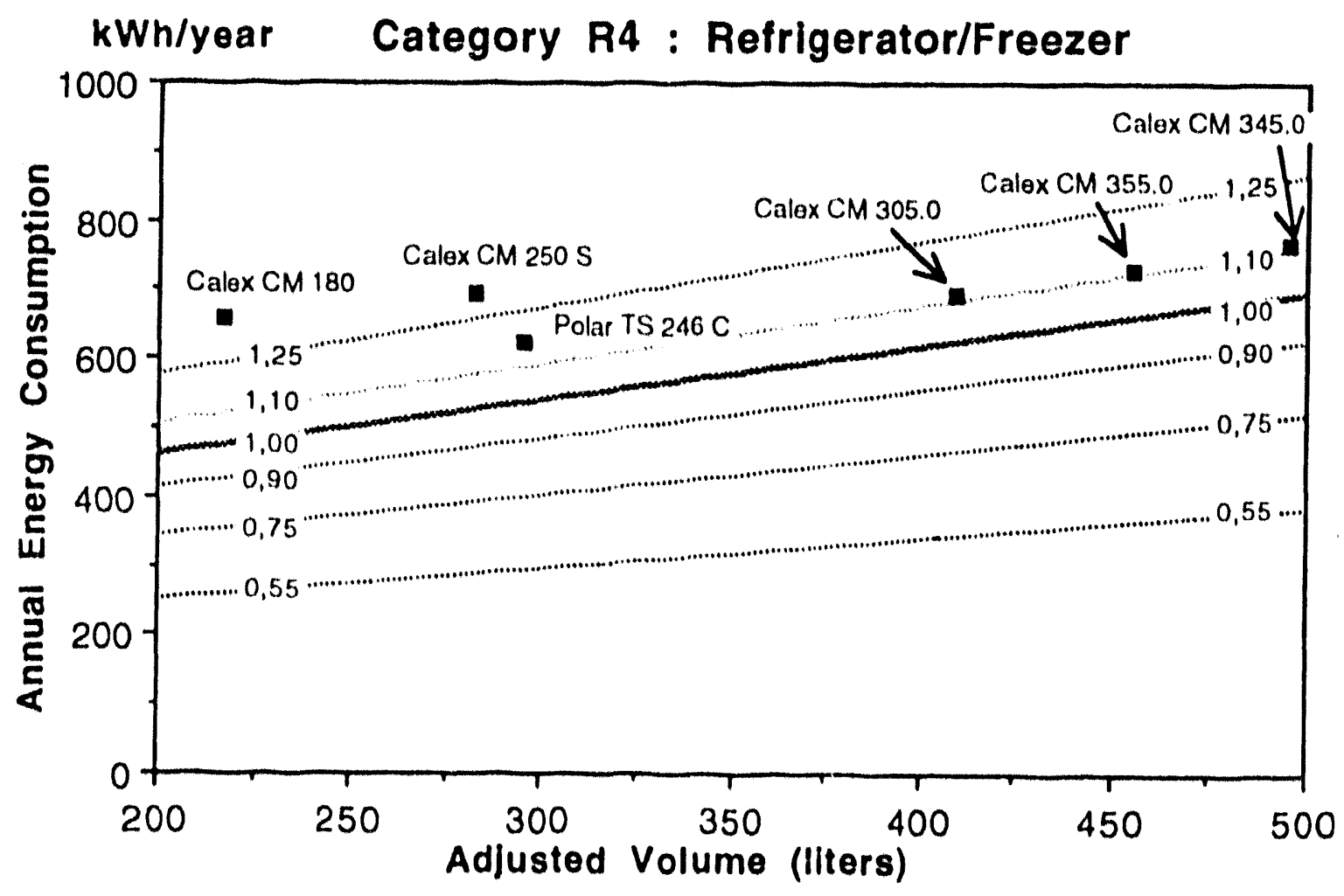

Figure 3 


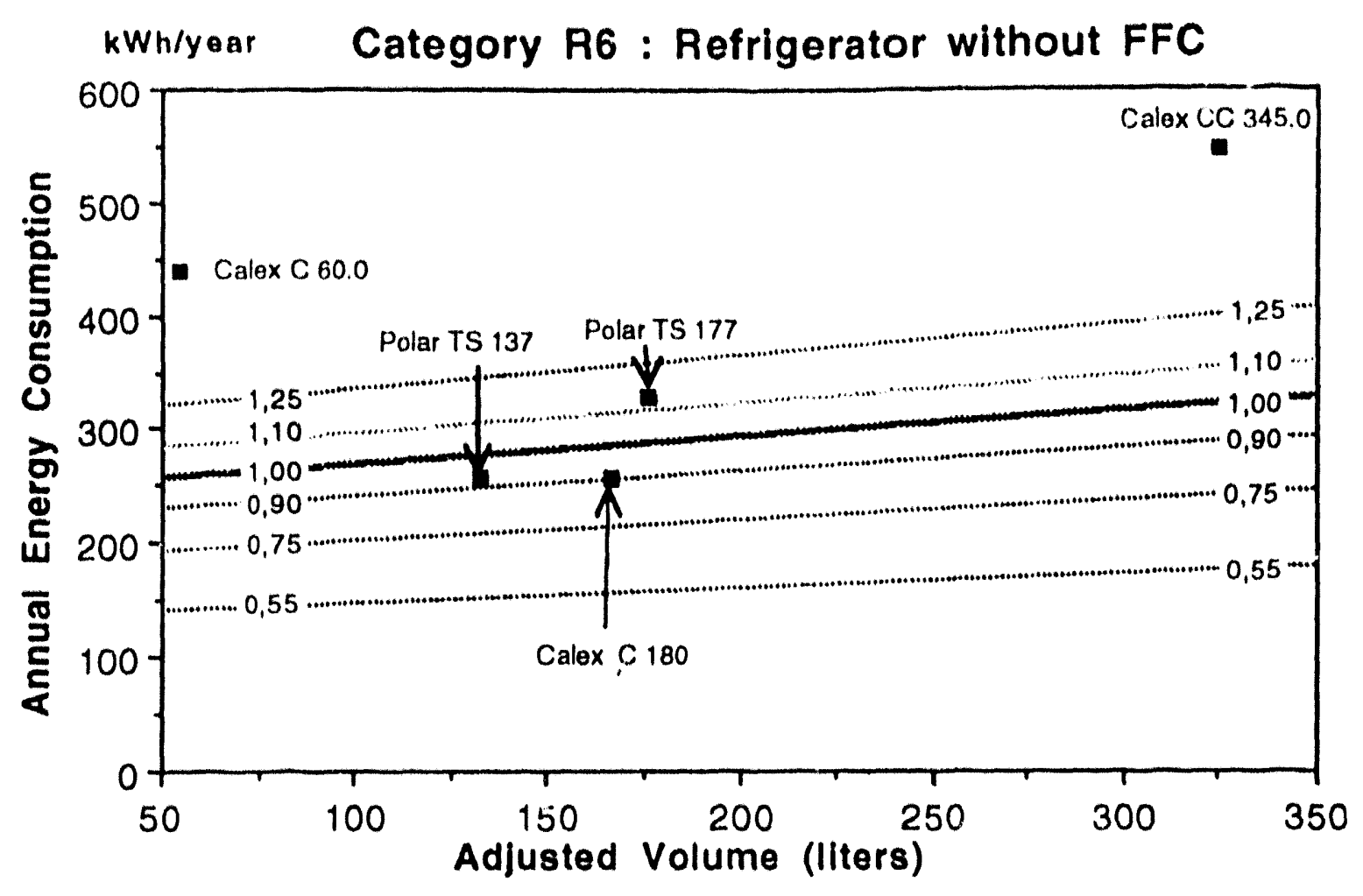

Figure 4 


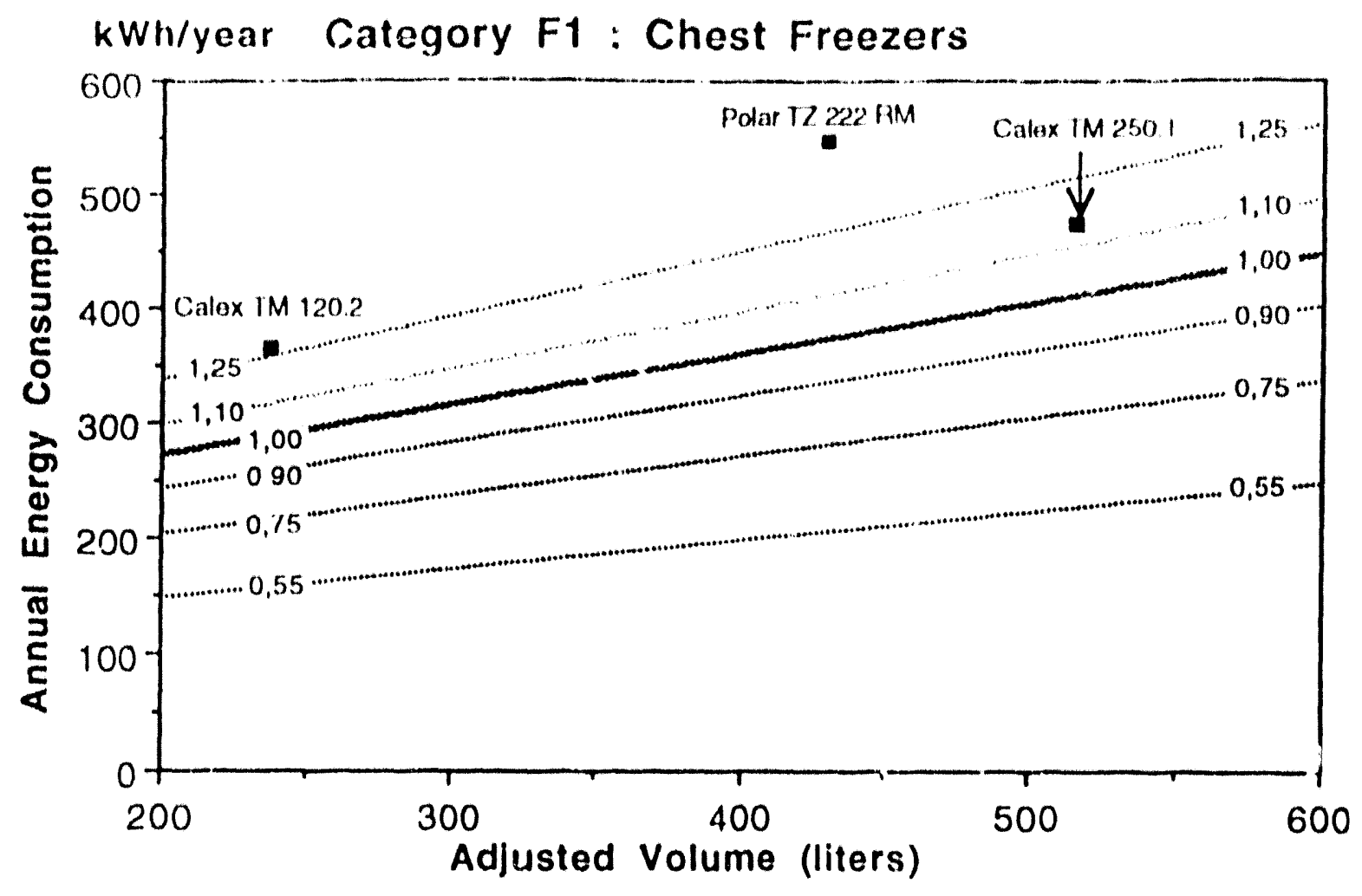

Figure 5

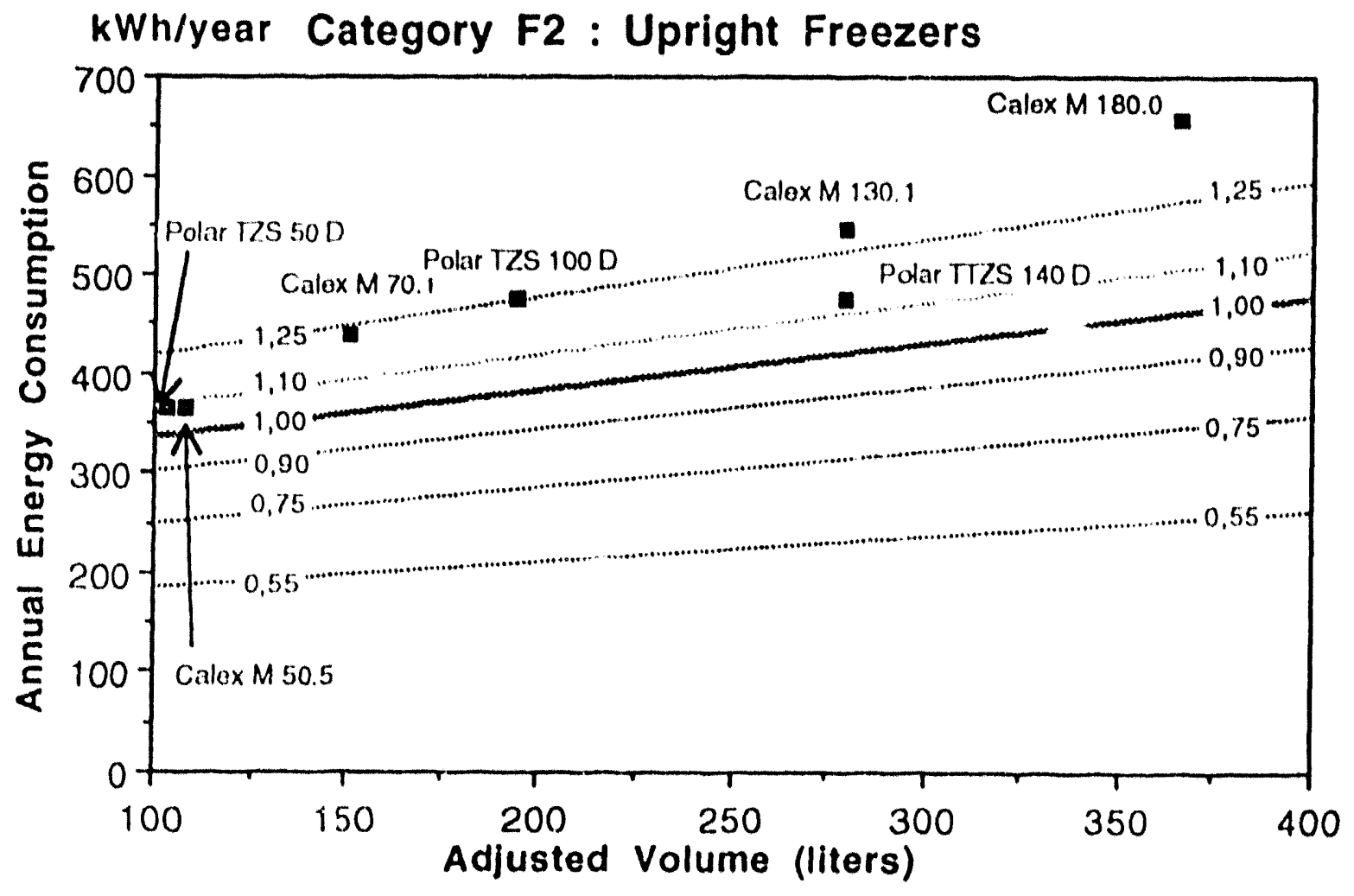

Figure 6 
Table 3. Statistics on Polar refrigeration appliances

\begin{tabular}{lccccccc}
\hline Model \# & $\begin{array}{c}\text { Star } \\
\text { rating }\end{array}$ & $\begin{array}{c}\text { GEA } \\
\text { cat. }\end{array}$ & $\begin{array}{c}\text { Total } \\
\text { volume } \\
\text { (liters) }\end{array}$ & $\begin{array}{c}\text { Freezer } \\
\text { volume } \\
\text { (liters) }\end{array}$ & $\begin{array}{c}\text { Energy } \\
\text { cons. } \\
\text { (kWh/day) }\end{array}$ & $\begin{array}{c}\text { Produc. } \\
1991 \\
\text { (units/yr) }\end{array}$ & $\begin{array}{c}\text { Retail } \\
\text { cost-7/92 } \\
(\text { (o)(0) Zl) }\end{array}$ \\
\hline REFRIG. W/FFC & & & & & & & \\
TS 138/136 & 2 & R2 & 132 & 16 & 0.80 & 60,000 & 2235 \\
TS 135 & 2 & R2 & 132 & 10 & 0.80 & 60,000 & 2235 \\
TS 176 & 2 & R2 & 176 & 16 & 1.04 & 40,000 & 2605 \\
TS 137 & 0 & R6 & 132 & 0 & 0.70 & 5,000 & 2330 \\
TS 177 & 0 & R6 & 176 & 0 & 0.90 & 5,000 & -- \\
TS 230 & 2 & R2 & 226 & 15 & 1.10 & 10,000 & 2880 \\
REFRIG-FREEZER & & & & & & & \\
TS 246 C & 4 & R4 & 240 & 48 & 1.70 & 50,000 & 4120 \\
\hline FREEZERS & & & & & & & \\
TZS 50 D & 4 & F2 & 50 & 48 & 1.00 & 5,000 & 2000 \\
TZS 100 D & 4 & F2 & 100 & 90 & 1.30 & 60,000 & 2780 \\
TZS 140 D & 4 & F2 & 140 & 130 & 1.30 & 20,000 & 3500 \\
TZ 222 RM & 4 & F1 & 210 & 200 & 1.50 & 20,000 & 3090 \\
\hline
\end{tabular}

Source for volume and energy use data is Polar product brochures.

a. The exchange rate in $7 / 92$ was 13,500 Zloty per U.S. dollar.

The relative energy efficiency of the Polar appliances varies among categories. For refrigerators with a 2-star frozen food compartment (FFC), the very small Polar models use slightly less energy than the EC average, whereas the larger 2-star models use about 10\% more. The same applies for refrigerators without a FFC (of which relatively few are produced). Polar's 4-star refrigerator/free\%er uses roughly $15 \%$ more electricity than the EC average.

Based on the estimate cited earlier that around two-thirds of Polish refrigerator sales are of larger models, it may be that the relatively-efficient small models are mainly intended for the export market and may utilize the imported and more efficient compressors. In general, the compressors used for very small refrigerators are less efficient than those available for larger sizes, so the models produced in the EC in the very small sizes (which occupy a tiny share of the EC refrigerator market) are mostly not very energy-efficient.

For upright freezers, the most popular Polar model (TZS 100D) uses $25 \%$ more than the EC average, while the other two models use around $10 \%$ more. For chest freezers, the Polir model's energy use is nearly $50 \%$ higher than the EC average.

\subsection{Potential for Improving Energy Efficiency}

The above comparison makes obvious that there is considerable room for improving the energy efficiency of most of Polar's models. An engineering analysis of the impact of making particular design changes to Polar's models was beyond the scope of this study. To illustrate the degree of improvement that can result from introducing various measures, we present results from the study (cited above) that was done for the Commission of the EC by the Group for Efficient Appliances (GEA). While the study 
refers to the situation in Western Europe, the results illustrate the approximate magnitude of savings that might be achievable in Poland and elsewhere in Easiem Europe.

The main design options for improving the energy efficiency of refrigerators and freezers that are technically feasible using today's mass production equipment are: (1) Increased door irsulation; (2) Increased cabinet insulation; (3) Increased evaporator surface; (4) Increased condensor surface; (5) Increased evaporator heat capacity; (6) Increased condensor heat capacily; (7) Use of a higher-efficiency compressor; and (8) Decreased door leakage. Application of these options results in somewhat higher initial cost in exchange for energy savings over the lifetime of the appliance. The cost-effectiveness of the options depends on the value of the future energy savings that they bring, which in tum depends on the price of electricity and the discount rate used.

The GEA estimated the extra cost and energy savings resulting from application of the above measures relative to baseline models in each appliance category. ${ }^{8}$ We modified the GEA economic analysis by using the expected residential clectricity price in Poland in late 1993 , which is about $\$ 0.07 / \mathrm{kWh}$ (converted using exchange rate), and by using a $10 \%$ rather than a $5 \%$ discount rate (reflecting the greater opportunity cost of capital in Poland). ${ }^{9}$ As shown in Table 4, many of the energy-saving design options in the R2 refrigerator, R4 refrigerator-freezer, and upright frecer categories (in which the majority of devices made in Poland fall) have a simple payback period of less than five years and a cost of conserved energy less than $\$ 0.07 / \mathrm{kWh}^{10}$ If we select the most efficient design that has a payback of five years or less (relative to the baseline model), the annual energy savings would be $4.3 \%$ for the R2 refrigerator, $32 \%$ for the $\mathrm{R} 4$ refrigerator-freezer, and $37 \%$ for the upright freezer. The estimated increase in purchatse price for these designs (under Western European conditions) is $10 \%, 8 \%$, and $8 \%$, respectivcly.

The baseline models used in the GEA analysis consume slightly less energy than the EC average shown in Figures 2 through 6. In those categories where the Polar appliances use more energy than the baseline model, the degree of energy savings resulting from moving to the more efficient design should be greater than cited above. Lack of information on the technical specifications of the Polar appliances precluded us from estimating the degree of improvement that would result from application of particular design options, but there is obviously much scope for reducing energy use.

The economics of making design changes to Polish appliances are more uncertain. Whereas the additional cost of particular design options can be estimated with reasonable accuracy for Westem Europe, the situation in Poland is less clear. The extra cost of using a more efficient compressor cian be easily determined, but many of the measures 10 enhance efficiency would be connected with an overiai re-tooling of the production facilities. In this situation, calculating the marginal cost of encrgy-saving design options is complicated. Even so, the GEA analysis suggests that substantial energy silvings are available for a relatively modest increase in cost.

Some degree of improvement is possible with Polar's existing plant. For example, Polar could use the more efficient compressors that are currently mounted only on units intended for expont on units for the domestic market. Polar is currently working on a new refrigerator-frecer designed to address both CFC phasing out and improvement in energy efficiency. We are uncertain as to how much more efficient and costly this unit will be relative to existing models.

\footnotetext{
8 The additional cost refers to the purchase price; the manufacturer costs were multipled by an estimate of the averige markup factor for the refrigerator and freezer industry.

9 The expected price is from the Polish Ministry of Industry and Trade, as given in material provided by FEWE.

10 The cost of conserved energy expresses the annualized, discounted incremental capital cost of a measure divided hy lhe ant nual energy savings.
} 
Table 4. Costs and energy savings for refrigerator and

freezer design options: Western Europe results modified for Poland

\begin{tabular}{|c|c|c|c|c|}
\hline & $\begin{array}{c}\text { Purchase } \\
\text { price } \\
\text { (US\$) } \\
\end{array}$ & $\begin{array}{c}\text { Energy } \\
\text { use } \\
(\mathrm{kWh} / \text { year }) \\
\end{array}$ & $\begin{array}{c}\text { Payback } \\
\text { period } \\
\text { (years) }\end{array}$ & $\begin{array}{c}\text { Cost of } \\
\text { conscrved energy } \\
\text { (US cents/kWh) }\end{array}$ \\
\hline \multicolumn{5}{|l|}{ REFRIGERATOR WITH 2-STAR FFC } \\
\hline 0 Basecase model & 578 & 335.3 & - & - \\
\hline $1=0+$ Incr. door insul. $(+15 \mathrm{~mm})$ & 585 & 299.4 & 2.2 & 2.8 \\
\hline $2=1+$ Decreased door leakage & 586 & 293.1 & 2.3 & 2.9 \\
\hline $3=2+$ Optimized compressor & 599 & 257.9 & 3.1 & $4 .()$ \\
\hline $4=3+$ Increased cabinet insul. $(+15 \mathrm{~mm})$ & 626 & 204.3 & 4.3 & 5.4 \\
\hline $5=4+$ Incr. door insul. $(+15 \mathrm{~mm})$ & 6.33 & 191.4 & 4.4 & 5.6 \\
\hline $6=5+$ Increased cabinet insul. $(+15 \mathrm{~mm})$ & 6.59 & 166.4 & 5.6 & 7.1 \\
\hline $7=6+$ Doubled evap. heat capacity & 673 & 161.8 & 6.4 & 8.1 \\
\hline $8=7+$ Doubled condensor heat capacity & 684 & 159.0 & 7.0 & 8.8 \\
\hline \multicolumn{5}{|l|}{ REFRIGERATOR-FREEZER 4-STAR } \\
\hline 0 Basecase model & 947 & 591.1 & - & - \\
\hline $1=0+$ Incr. door insul. & 960 & 520.2 & 2.2 & 2.4 \\
\hline $2=1+$ Improved compressor & 967 & 496.6 & 2.4 & 2.7 \\
\hline $3=2+$ Increased door insul. to $35 / 65 \mathrm{~mm}$ & 973 & 481.9 & 2.8 & 3.1 \\
\hline $4=3+$ Decreased door leakage & 976 & 475.5 & 2.9 & 3.2 \\
\hline $5=4+$ Increased cabinet insul. to $45 / 65 \mathrm{~mm}$ & 1000 & 429.2 & 3.8 & 4.2 \\
\hline $6=5+$ Increased cabinet insul. to $60 / 80 \mathrm{~mm}$ & 1024 & 398.9 & 4.7 & 5.1 \\
\hline $7=6+$ Doubled condensor surface & 1075 & 345.0 & 6.0 & 0.6 \\
\hline $8=7+$ Doubled condensor heat capacity & 1101 & 321.5 & 6.6 & 7.3 \\
\hline $9=8+$ Doubled evaporator surface & 1121 & 314.2 & 7.3 & 8.0 \\
\hline $10=9+$ Doubled evap. heat capacity & 1172 & 298.8 & 8.9 & 9.8 \\
\hline \multicolumn{5}{|l|}{ UPRIGHT FREEZER } \\
\hline 0 Basecase model & 697 & 439.8 & - & - \\
\hline $1=0+\operatorname{Improved~compressor~}$ & 700 & 387.0 & 0.6 & 0.7 \\
\hline $2=1+$ Decreased door leakage & 702 & 376.8 & 0.8 & 0.9 \\
\hline $3=2+$ Increased door insul. to $35 \mathrm{~mm}$ & 706 & 362.9 & 1.3 & 1.5 \\
\hline $4=3+$ Increased cabinet insul. to $45 \mathrm{~mm}$ & 724 & 319.8 & 2.6 & 2.8 \\
\hline $5=4+$ Increased door insul. to $50 \mathrm{~mm}$ & 728 & 310.4 & 2.8 & 3.0 \\
\hline $6=5+$ Increased cabinet insul. to $60 \mathrm{~mm}$ & 746 & 286.0 & 3.7 & $+(1)$ \\
\hline $7=6+$ Doubled condensor heat capacity & 753 & 276.4 & 4.0 & 4.4 \\
\hline $8=7+$ Doubled evaporator surface & 798 & 246.6 & 0.0 & 0.6 \\
\hline $9=8+$ Doubled condensor surface & 846 & 219.9 & 7.0 & 8.7 \\
\hline
\end{tabular}

Source for cost and energy use data: Group for Efficient Appliances, Study for the Commission of the European Communities on Energy Efficiency Standards for Domestic Refrigeration Appliances, March 1993.

The cost of conserved energy assumes a $10 \%$ real discount rate. The simple payback uses an electricity price of \$0.07 per kWh. Equipment lifetime: R2 refrigerator -- 12 years; Refrigerator-freezer R4 -- 16 years;

Freezer -- 16 years. Basecase model volume (liters): R2 refrigerator - $169+19$ (FFC);

Refrigerator-freezer R4 -- 171 + 86; Freczer -- 167 . 


\subsection{Potential Energy Savings from Improving Energy Efficiency}

Lack of data precludes us from making more than a very rough estimate of the magnilude of electri city savings that could result from improving the energy efficiency of refrigeration appliances made in Poland. Apart from the uncertainty as to how much specific consumption ( $\mathrm{kWh} / \mathrm{day}$ ) could he reduced through application of various design options, an important piece of missing information is the volume of sales of various models on the Polish market.

The following exercise uses the Polar data to give a rough indication of the magnitude of potential electricity savings (see Table 5). First, let us assume that the energy consumption of each of the Polar models is brought down to the EC "average" specific to its product catcgory and adjusted volume (the solid line in Figures 2-6). Note that the energy use of Polar's three small refrigerators is already below the EC average, so we assume no savings for these models, which together accounted for aboul hall of Polar's refrigerator production in 1991. Second, let us assume that the production volume of these models is the same as in 1991 (in fact, some change in the markel is likely as the economy recovers). Relative to the old energy consumption levels, the resulting annual clectricily savings would amount (1)

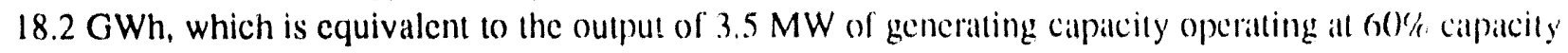
factor. Approximately $60 \%$ of the overall (iWh savings are accounted for by freezers. Not all of the salvings would occur in Poland, however, since some of the appliances are exported. Although only $60 \%$ of Polar's production goes to the domestic market, the share of energy satvings in the domestic markel would probably be greater, since the exported models appear to be more efficiemt. Note also that these sivings only consider appliances made by Polar, which account for about (wo-thirds of total Polish production. 
Table 5. Electricity savings from improving the energy efficiency

of Polar refrigeration appliances: an illustration

\begin{tabular}{|c|c|c|c|c|c|c|}
\hline \multirow[t]{2}{*}{ Model \# } & \multirow{2}{*}{$\begin{array}{c}\text { GEA } \\
\text { catcgory }\end{array}$} & \multicolumn{3}{|c|}{ Test energy use } & \multirow{2}{*}{$\begin{array}{c}\text { Production } \\
\text { 1991 } \\
\text { (units/yr) } \\
\text { C }\end{array}$} & \multirow{2}{*}{$\begin{array}{l}\text { Eleclricily } \\
\text { savings } \\
\text { (CWh/yr) }\end{array}$} \\
\hline & & $\begin{array}{c}\text { Polar } \\
(\mathrm{kWh} / \mathrm{yr}) \\
\text { A }\end{array}$ & $\begin{array}{c}\text { EC average } \\
(k W h / y r) \\
B\end{array}$ & $\begin{array}{l}\text { EC best } \\
(\mathrm{kWh} / \mathrm{yr})\end{array}$ & & \\
\hline \multicolumn{7}{|c|}{ REFRIG. W/FFC } \\
\hline TS $138 / 136$ & R2 & 290 & 310 & 250 & $6(0,0)(0)$ & .. \\
\hline TS 135 & $\mathrm{R} 2$ & 290 & 305 & 250 & $60,()(0)$ & - \\
\hline TS 176 & $\mathrm{R} 2$ & 380 & 3.30 & 24.5 & $40,(1)(0)$ & $2 .(x)$ \\
\hline TS 137 & R6 & 255 & 275 & .. & $5,()()()$ & .. \\
\hline TS 177 & R6 & 3.30 & 280 & .. & $5 .(0)(0)$ & (1).2.5 \\
\hline TS 230 & R2 & 4()() & 350 & 245 & $10 .(0)(1)$ & 0.50 \\
\hline \multicolumn{7}{|c|}{ REFRIG-FREEZER } \\
\hline TS $246 \mathrm{C}$ & R4 & 620 & 525 & 37.5 & $50,()(0)$ & 4.7 .5 \\
\hline \multicolumn{7}{|l|}{ FREEZERS } \\
\hline TZ 222 RM & F1 & 550 & 30,5 & 160 & $2(1,0)(1)$ & 3.70 \\
\hline TZS 50 D & F2 & 36.5 & 34() & -. & $5,()()()$ & 0.13 \\
\hline TZS 100 D & $\mathrm{F} 2$ & 475 & 380 & 255 & $60,0)(0)$ & 5.70 \\
\hline TZS 140D & F2 & 475 & 415 & 275 & $20,()()()$ & 1.20 \\
\hline
\end{tabular}

Source for actual energy use data is Polar brochures. The EC alverage refers to the point on the reference line (1.0) in Figures 2-6 that corresponds to the adjusted volume of the Polar model. Data for EC best were taken from graphs in the GEA sludy ciled in Table 4

a. If $(A-B)$ is less than zero, savings are zero.

\section{POLICY OPTIONS FOR IMPROVING EFFICIENCYY OF REFRICIERATION APPIIANCES}

In the past, Poland's communist government had some regulations with respect lo energy elficiency' for production of certain appliances, but they were not strictly enforced. In recent years, there has been discussion about instituting energy labelling recpuirements for appliances, but the govemment hits nol laken any action, perhaps waiting until the EC decemines its own procedures.

In Westem Europe, the prospects for extablishing an energy labelling scheme and minimum efficiency standards for appliances appear lavorable. In 1990), the Nordic countries (Sweden, Norwaly, Denmark, and Finland) established a commission of experts (NORDNORM) lo prepare the ground for appliance labelling and minimum efficiency standards. The Commission of the EC is planning 10 institute energy labelling for refrigerators and freezers in 199.3. Minimum efliciency standards, bisted on the GEA study cited above, may follow.

While imports from the EC countries play only a small role in the Polish markel for most major appliances, actions taken by the EC will have a significant impact on Polish appliance production, since the EC market is important to Polar. Unless Polar makes improvements in energy efliciency, cuergy labelling could hurt sales in the EC somewhat, since it would indicate the relatively low elliciency of their appliances (depending on which models it exports). Minimum elficiency standards could pose a 
more serious problem. The ability of Polar to meet the EC's efficiency standards may depend on whether they are able to attract the capital investment needed to modertize their appliance production. If they succeed in such modernization, some technical improvements would undoubtedly be incorporalled in models for the domestic market as well as the export market, although the domestic models would probably not be as energy-efficient as the export models due to the need to maintain lower prices in order to sell in the domestic market.

Once EC labelling requirements are established, it would be a simple matter for the Polish government to mandate such labels for appliances sold in Poland. How such requirements would alfect the appliances imported from the former Soviet Union is uncertain; it would be necessary 10 isscertain whether the manufacturers in these countries are following the appropiate lesting procedures. II is likely that these manufacturers would also want to export to the EC market and would thus conform to the pro. cedures adopted by the EC.

Whether energy labelling would have much affect in moving the Polish market loward higher energy efficiency is uncertain. Studies of the impact of appliance energy labelling in North America, where it has been required for many years, suggest that labelling has a relatively simall eflect on consumer decision-making." In part, this reflects the lack of emphasis that retialers have placed on labels. L.abelling may stimulate design changes by manulacturers concemed that the poor compaltative pertormante of their products could negatively alfect their reputition.

If it wished to have a greater effect on appliance elficiency, the Polish govemunem could establish minimum efficiency standards based on the EC procedures. (iiven the differences in the Polisth mirkel (including lower electricity prices), these stinddards would probibly be less stringent thath these thall maly

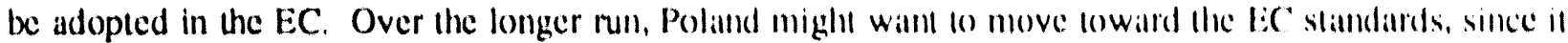
secks membership in the EC, but it would be desirable lo delermine the efliciency levels that are most beneficial for the Polish situation. Adoption of the L:C Lesting and labelling procedures by Poland would make it simple to exclude from the market lhose appliances that did not meet a given stind and

In considering minimum efficiency standiards, the Polish government must like account of the need for considerable capital investment 10 modernize appliance production. It must also heal 11 mind that most Polish consumers are very sensitive to the initial cost of an appliance. (On the ofluer himd. mete efficient appliances will help consumers by miligating lleir risk from rising clectricily prices. Manly energy-saving measures can be incorporalled al relatively low cost, provided the cappital investment for re-tooling can be spread over a large enough production. In this context, minimum efliciency standards could help in reducing the risk associaled with invesiment in modemising appliance production by guarantecing a domestic market for the impioved models. (iiven the size of the Polish market, and llie considerable potential for replacement of existing appliances as llhe economy recovers, such a gualtantec could prove attractive to foreign companies considering investment in Poland. Such investmem 1 ould bring both capilal and technical expertise.

Minimum efficiency standards would eliminate the keast energy-edlecient ilpplialleces from llic market, but would not necessarily encourage manufacture:s 10 go very lat beyond the standarid. If the standard is relatively weak, the incorporation of additional encrgy-siving design options is likely lo be cosl-effective from a societal perspective.

Programs conducted by electric utilities to encourange end-use elliciency could platy int impontant role in stimulating consumer interest in more ellicient models. Programs that pay a rebatte fo customers who purchase energy-efficient models have proven popular and successtul in the 1/.S. Prowiding!

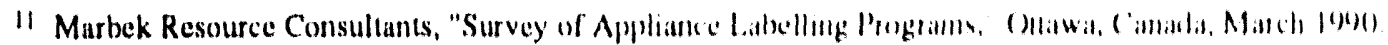


incentives to appliance retailers to promote high-efficiency models is another option used by some U.S. utilities. An alternate approach that is simpler 10 administer involves directly suhsidiring the price of more efficient models through payments to the manufacturers (use of this s..echod in Poland could raise questions of faimess with respect to foreign manufacture rs). Any utility payments (o encourage appliance efficiency must be evaluated in the larger context of utility involvement in demand-side mantgement (DSM). Preliminary work towards creation of an integrated resource planning framework in which $1 / x^{\circ}$ range of DSM options can be analyzed is now underway for the Polish power sector. ${ }^{12}$

A final approach that bears consideration is for the government to encourage large housing companies that purchase appliances in bulk 10 purchase high-efliciency models, 1 ... providing a markel for producers. The government could provide credible information showing the cost savings of these models. This approach has been fostered in Sweden. ${ }^{13}$ Financial support for the purchase of the high-efliciency models could potentially come from utilities as part of DSM activities. Such a program mighll also he supported with funds from the UNDP/World Bank Cilobal Environmentil Facility.

\section{CONCLUSION}

The energy efficiency of refrigeration appliances produced in Poliand for domestic salle is sulstian tially lower than the average for similar models made in Western Europe. The cost-eflictiveness on vari ous design options for increasing energy efficiency is uncertion, hut it alpecars likely thall considerable improvenent would be economic from a socictal perspective. Over lime, such improvement could have at substantial impact on electricity generation refuirements, and, allong will ollher electricily end-use

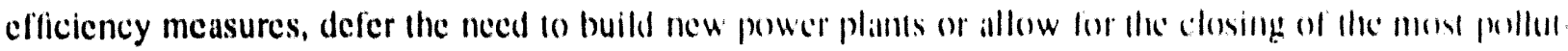
ing coal-fired power plants.

The facilities of the main Polish manulacturer of refrigeraltion appliances are in greall need of modemization or perhaps even replacement will a llew lactory. II will probably reguire much cilpilial investment, most likely from a Westem appliance company, 10 produce appliancess of higher gualiey and

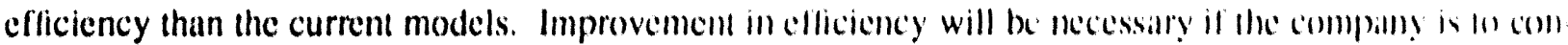
tinue to expon to Westem Europe, which is probibly essential lo its viability

Govemment policies and utility energy elliciency programs could help lo beild a manked for mote efficient appliances in Poland, and thereby reduce the risk of investment in new production ciapleily. The impending introduction of a lesting and labelling scheme in Western lumepe will provide a hasis lor labelling in Poland, as well as for minimum efliciency standards. A realistic applatisal of the inveroment needs of the Polish companies is required. The Europe:an Bank for Reconstruction and Development or

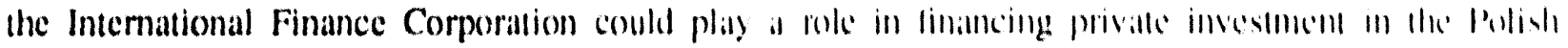
appliance industry.

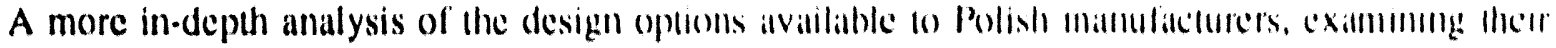
energy savings and potential cost in full production, would facilitille lle developmente of approprialle poli. cies and programs. Support for such analysis, which must be conducted collaborallively will llie lollish companies, should be a high priority for lechnical alssistince.

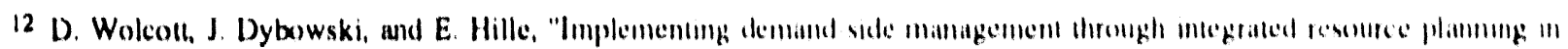

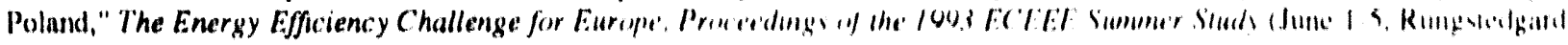
Donmark).

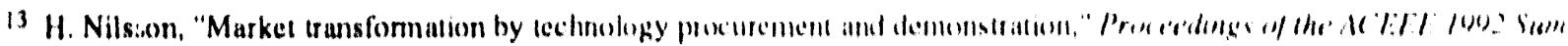

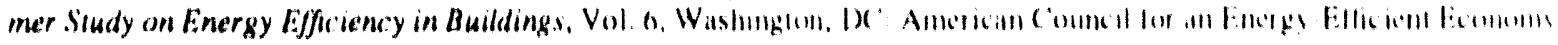



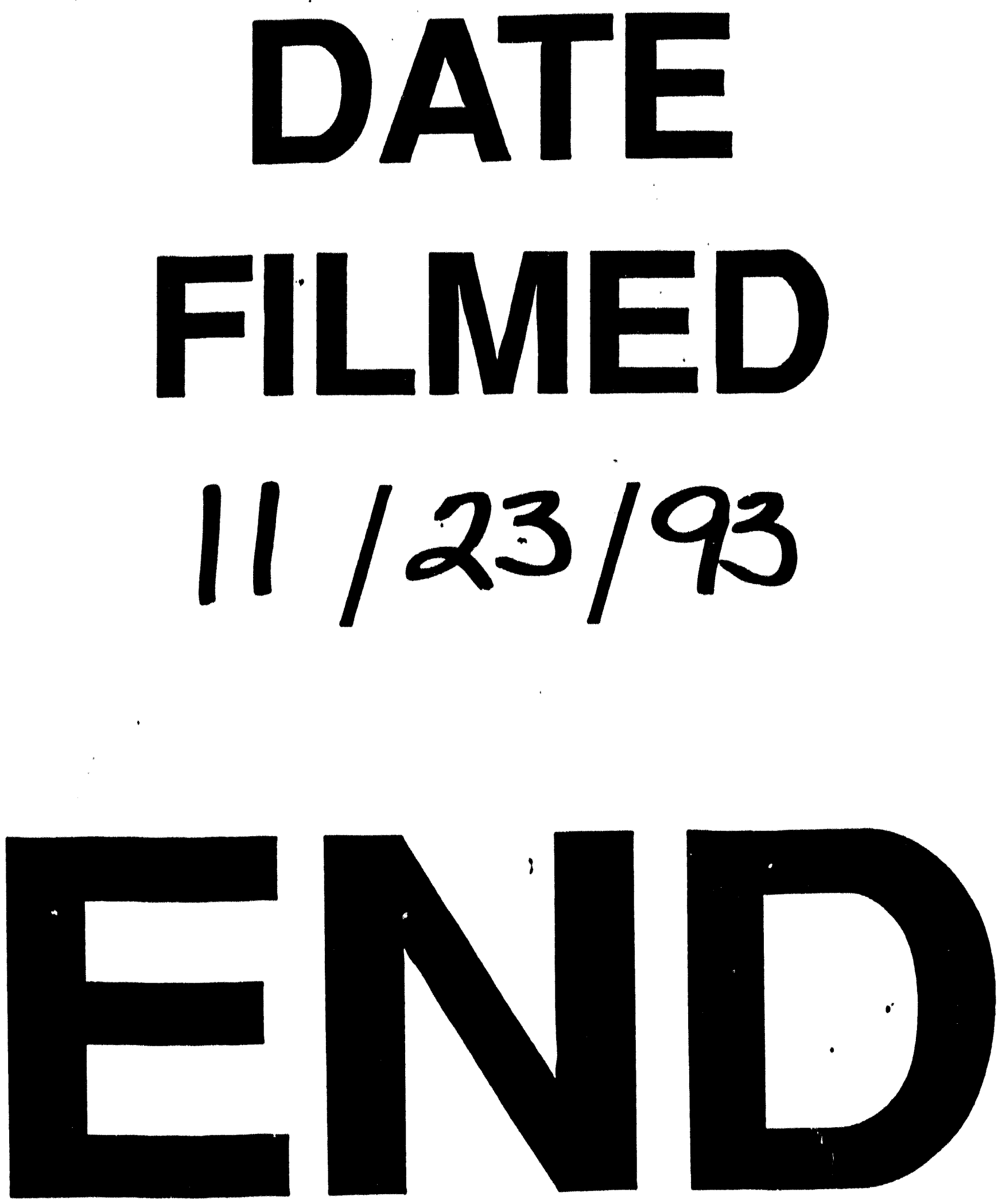
